\title{
O Hóspede da Hora Tardia
}

Jaa Torrano

Na segunda tragédia da trilogia Orestéia, o segundo episódio se compōe de duas cenas separadas pela prece à Persuasão dolosa e dominadas ambas pela presença da Deusa invocada na prece (C. 653-782).

Na primeira cena, Orestes, recebido no palácio real de Argos por um servo, apresenta-se à rainha Clitemnestra, ocultando-se sob falsa identidade, como um hóspede dauliense que vem da Fócida com a notícia da morte de Orestes e o pedido de instruçōes sobre os funerais. A notícia falsa do falso mensageiro cria a aparente e falsa circunstância de que para Clitemnestra se dá dupla perda: a do filho por ela gerado e a da ameaça pesada que sobre ela impende.

O discurso de Clitemnestra (C. 691-718) a respeito da convincente e falsa notícia da morte de Orestes fala do ponto de vista do palácio de Argos, que se declara atingido por invencível imprecação ("Ó Praga inelutável deste palácio" C. 692). Nesse sentido, o discurso parece sincero e é convincente de sua verdade, porque Clitemnestra não fala de si nem como mãe nem como sob tácita ameaça, mas fala pelo palácio.

A imprecaçāo (Ará, C. 692), invocada no discurso da rainha, remete à praga de Tieste contra Atreu, quando do banquete em que este the deu de comer carne dos filhos (A. 1590ss.); Orestes, abrigado pela hospitalidade de Estrófio na Fócida, parecia 
salvo pela prudência, mas a notícia diz que não escapou ao golpe da imprecação. A esperança de que se curasse a maligna loucura (bakkheía kakês, C. 698) revelou-se traiçoeira: a noticiada morte de Orestes se apresenta como um acontecimento numinoso em que se cumpre a imprecação; essa notícia é falsa, mas é ironicamente verdadeira a conclusão, tirada dessa notícia pela rainha, de que a maligna loucura do palácio de Argos ainda não se curou. A "baquéia" que infesta o palácio é maligna, porque termina em morte, e ainda não está curada, porque sua irrupção ainda uma vez é manifesta no palácio. Nesse sentido, o discurso da rainha é verdadeiro, nāo no que diz respeito aos interesses imediatos da rainha, mas no que concerne aos acontecimentos por virem no palácio de Argos. A ironia consiste em que a rainha aparentemente está longe de perceber em que sentido suas palavras são verdadeiras, mas está convicta de que sejam verdadeiras, persuadida com falsa notícia dada por falso mensageiro.

A primeira cena se completa com as palavras de Orestes (C. 700-6) e de Clitemnestra (C. 707-18) a respeito das circunstâncias em que para o hóspede deste palácio se dá

$$
\begin{aligned}
& \text { ser conhecido e hospedado. O que é } \\
& \text { mais grato aos hóspedes que o hóspede? }
\end{aligned}
$$

O coro intervém quando Clitemnestra se dispôs a comunicar essas circunstâncias aos que têm o poder no palácio e deliberar acerca delas (têsde symphorãs péri. C. 719).

Nesse momento em que a comunicação e a deliberação dos que têm o poder ainda estão por virem, a intervenção do coro se dá pela invocação da Senhora Terra e da Senhora Orla do túmulo do herói cujas honras o coro celebrava e presidia a celebração. $O$ coro, portanto, intervém na ação por seu caráter de oficiante das honras heróicas e por suas preces aos ínferos. Trata-se, pois, de uma dignidade conferida pelos procedimentos 
cultuais, a qual dá às vozes do coro o poder de intervirem na ação.

agora é hora de Persuasão dolosa

vir à liça e de sob a terra Hermes

noturno pôr-se a caminho

dos combates com facas letais.

(C. 726-9)

Na hora tardia, quando "o carro da Noite se apressa tenebroso" (C. 660s), mencionada por Orestes ao ser atendido pelo servo junto à porta do páteo, o tardio da hora se revela pela presença das Divindades noturnas, Persuasão dolosa e Hermes noturno que vêm de sob o chão trazendo consigo os meios de satisfazer-se a cólera dos ínferos.

A essa prece aos Deuses noturnos, pontuada pela urgência da hora de comparecer ao combate, segue-se o anúncio de Cilissa, antiga ama de Orestes. Sua aparente tristeza constitui para o coro um indício visível de como o hóspede age, e o coro the pergunta aonde vai (C. 730-3).

A resposta da ama à pergunta aonde vai abrange a descrição de seu estado de ânimo em contraste com a aparente atitude de Clitemnestra. A ama vai a Egisto com a mensagem da rainha de que venha o mais rápido e interrogue os hóspedes portadores da momentosa notícia. Vista pela ama, a rainha parece fingir perante servidores turvo luto pela notícia que antes the daria júbilo. Em contraste com o riso oculto atribuído por ela à rainha, a anciã manifesta a dor de perder a razão de seus antigos cuidados (C.73465).

Tão manifesta dor enseja gratidāo à palavra solidária, e a ama acolhe do coro o dúplice conselho de que mude a mensagem de vir acompanhado para vir desacompanhado e de que a transmita com jubiloso espírito. O que possa haver de enigmático para a anciã no conselho de que mude tão completamente $\circ$ 
estado de ânimo recebe com grande conforto a explicação de que "cuidam os Deuses dos seus cuidados deles"(C. 779).

O coro diz à ama tāo poucas palavras quanto necessárias para surtir o efeito persuasivo tanto junto à mensageira quanto junto ao destinatário da mensagem.

\section{CoÉforAs, 653-782 \\ ÉSQUILO \\ SEGUNDO EPISÓDIO}

Or. Servo! Servo! Ouve bater à porta do páteo.

Ó de casa! Ó servo! Servo! Ó do palácio!

Três vezes chamo por alguém do palácio,

se é mesmo hospitaleiro o lar de Egisto.

Se. Eia, escuto! Donde é o hóspede? Donde?

Or. Leva a notícia aos senhores do palácio, junto a quem venho e trago novidades.

Vai rápido que o carro da Noite se apressa

tenebroso, é hora de viajores lançarem

âncora nos palácios receptores de hóspedes.

Venha do palácio um portador de poder,

mulher soberana, homem porém é melhor,

pois o pudor no colóquio torna turvas

as palavras, com franqueza fala o homem

ao homem e o que se diz se faz claro.

Cl. Hóspedes, dizei-me se precisais de algo, pois há neste palácio o que vos convém, banhos quentes e lenimentos de males. 
agasalho e a presença de olhos justos. Se é preciso fazer algo mais cogitado, homens o fazem, a quem comunicaremos.

Or. Hóspede sou, dauliense, vindo da Fócida, e ao marchar portador da própria arma a Argos, tal qual aqui desatrelei os pés, estranho a estranho encontrou e falou, após inquirir e inteirar-se do percurso, Estrófio da Fócida (soube-o na conversa): "Já que, aliás, ó hóspede, vais a Argos, "junto aos pais, com toda justiça lembrado "diz que morreu Orestes, não te esqueças; "se prevalecer a opinião deles a trasladar, "ou domiciliado, em tudo sempre hóspede, "sepultá-lo, remete-nos estas instruçōes. "Agora os flancos de uma urna de bronze "recolhem a cinza do homem pranteado." Tanto ouvi e disse, mas se por acaso falo com os responsáveis e interessados, não sei; é provável que o pai o saiba.

$\mathrm{Cl}$. Ai de mim! Que pilhagem nos atinge!

Ó Praga inelutável deste palácio, como espreitas muitos e remotos bens: dominando de longe com arcos certeiros, dos meus me espolias nesta miséria! E agora Orestes: por prudência estava tirando o pé do brejo do extermínio

Agora a esperança, no palácio médica de maligno delírio, revela-se traidora.

Or. Eu junto a hóspedes tão prósperos queria por auspiciosas notícias ser conhecido e hospedado. O que é mais grato aos hóspedes que o hóspede? 
mpiedade seria isto em meu espírito: não cumprir tal promessa a amigos quando prometi e estou hospedado.

Cl. Não obterás algo menos digno de ti, nem serias menos amigo do palácio, outro por igual viria anunciar isso.

Mas é oportuno que hóspedes, após longa jornada, encontrem conforto.

Leva ao quarto de hóspedes do palácio a ele e ao servo que o segue na viagem e lá desfrutem os confortos do palácio. Ordeno-te fazê-lo com solicitude. Nós comunicaremos isto aos senhores do palácio e não carentes de amigos deliberaremos sobre esta conjuntura.

Co. Eia, ó fiéis servas do palácio, quando é que mostraremos o vigor das vozes por Orestes? Ó senhora Terra, senhora orla da tumba que agora cobres o corpo do régio capitão de navios, ouve agora, socorre agora: agora é hora de Persuasāo dolosa vir à liça, e de sob a terra Hermes noturno por-se a caminho dos combates com facas letais.

Parece que o hóspede perpetra o mal.

Vejo aqui a ama de Orestes em pranto. Cilissa, aonde vais fora do palácio? Angústia sem paga te acompanha. 
A. A rainha manda chamar o mais rápido Egisto aos hóspedes, para que mais claro o homem saiba do homem esta recém-dada notícia ao vir. Ante os servidores, finge um luto de olhos turvos, ocultando o riso por acontecimentos para ela bem sucedidos, e como a estar tudo mal para o palácio, pela nova que os hóspedes anunciam clara. Sim, ouvindo ele alegrará o seu espírito quando souber a palavra. Ó mísera sou, porque as antigas e confusas dores, insuportáveis neste palácio de Atreu, sofri e pungiram-me o coraçāo no peito, mas não ainda padeci dor como esta, pois os outros males aturei tolerante. É meu Orestes, desvelo de minha alma, a quem recebi da mãe e assim criei, e noctívagos eram os agudos vagidos

e suportei muitas e inúteis fadigas, pois o infante, tal como se fosse alimária, deve ser nutrido - não ? - como se falasse: nāo tem voz a criança ainda nas faixas, se a aflige a fome ou a sede, ou se urinou, o ventre novo das crianças é autônomo. Previdente disso, e creio que ludibriada muitas vezes, lavadeira de faixas infantis, lavar e nutrir são ambos da mesma função. Eu, com esta dúplice perícia das māos, recebi Orestes no interesse de seu pai, e agora mísera ouço que está morto. Vou até o homem lesivo deste palácio e se quiser ele ouvirá esta palavra. 
Co. Como, pois, manda-o vir equipado?

A. Como? Diz, para eu saber mais claro.

Co. Com seqüito ou com solitários passos?

A. Ordena levar sequazes lanceiros.

Co. Não anuncies isso ao hediondo senhor, Mas vá ele só, que o digam intrépido, exorta-o logo, com jubiloso espírito: no mensageiro palavra torta põe reta.

A. Mas sentes bem com este anúncio ?

Co. Mas se Zeus fizer mudarem-se os males?

A. Como? Orestes foi esperança do palácio.

Co. Não ainda. Mau adivinho diria isso.

A. Que dizes? Sabes algo além da notícia?

Co. Vai, anuncia, cumpre o mandado. Cuidam os Deuses de seus cuidados.

A. Irei e seguirei nisso tuas palavras.

Que o melhor nos seja dom dos Deuses! 